\title{
El propósito de la estructura del De principiis de Orígenes
}

\author{
Samuel Fernández \\ FACULTAD DE TEOLOGÍA \\ PONTIFICIA UNIVERSIDAD CATÓLICA DE CHILE \\ sfernane@uc.cl
}

Resumen: La estructura del De principiis ha intrigado a los estudiosos por varias décadas, debido a sus repeticiones, digresiones e irregularidades, que han impedido alcanzar resultados definitivos. Y si bien en el último siglo se han realizado significativos avances en las obras de Orígenes, la falta de datos sobre el contexto y el propósito del tratado deja espacio para múltiples hipótesis. De acuerdo a este artículo, el De principiis estaría básicamente estructurado por dos ciclos sucesivos pensados como un itinerario pedagógico para ofrecer la enseñanza eclesial al ambiente intelectual de Alejandría, que desprecia la fe de los simpliciores y que se siente atraído por la opción intelectual de los gnósticos. Estos sucesivos desarrollos de los mismos temas bajo diversas perspectivas, no serían fruto de sucesivas redacciones, sino más bien de un plan pedagógico proyectado por Orígenes.

Palabras clave: Orígenes, De principiis, Alejandría, teología primitiva.

Abstract: The structure of De Principiis has intrigued scholars for many decades, due to its repetitions, digressions and irregularities, which have prevented them from attaining definite results, and though during the last century, studies of Origen's work have made significant progress, the lack of data regarding the context and purpose of his treatise have left room for different hypothesis. According to this paper, De principiis would basically structured by two successive cycles intended as an pedagogical path to offer the teaching of the Church to the intellectual ambience of Alexandria, that scorns fides simpliciores and is attracted by intellectual way of Gnostics. These successive developments of the same subject under different perspectives would not be the result of successive redactions, but rather a pedagogical plan designed by Origen.

Keywords: Origen, De principiis, Alejandría, early theology. 


\section{INTRODUCCIÓN ${ }^{1}$}

La estructura del De principiis ha intrigado a los estudiosos desde hace ya muchas décadas, debido a sus repeticiones, digresiones e irregularidades. Si bien el último siglo se han realizado significativos avances en este punto, de todos modos, la falta de datos sobre el contexto y el propósito del tratado deja espacio para múltiples hipótesis.

Sobre la estructura del tratado, el aporte fundamental sigue siendo el de dom Basilius Steidle, de 1941. Sobre la base del libro de W. Völker (que sostiene que el De principiis sería un reflejo de la actividad escolástica de Orígenes), Steidle estableció, por una parte, que la división en cuatro libros -aún siendo original- no respondía al plan de una obra dividida en cuatro partes, sino a las exigencias materiales de una obra escrita en rollos; y, por otra, mostró que el contenido del tratado se debía dividir en tres ciclos, que sucesivamente tratan de Dios, de las creaturas racionales y del mundo: una visión sintética (I, 1 - II, 3); una visión más amplia y analítica (II, 4 - IV, 3) y, finalmente, la recapitulación (IV, 4). Posteriormente, varios estudiosos continuaron críticamente el camino abierto por B. Steidle, en especial, M. Harl, M. Simonetti, G. Dorival y J. Rius-Camps ${ }^{2}$. Este aspecto de la historia de la investigación ha sido descrito por Giulia Sfameni Gasparro en un amplio y bien documenta-

1 Este trabajo forma parte de los resultados del proyecto Fondecyt 1120687 (2012-2014).

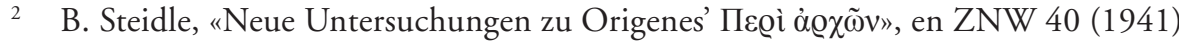

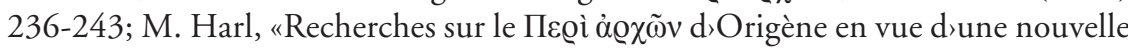
édition: la divition en chapitres», en Studia Patristica III, (Berlin 1961), 57-67; M. Simonetti, "Osservazioni sulla struttura del De Principiis di Origene», Rivista di Filologia e d'Istruzione Classica 40 (1962) 273-290; 372-393; P. Kübel, «Zum Aufbau von Origenes' De principiis», en VC 25 (1971) 31-39; M. Harl, «Structure et cohérence du Peri Archôn», en Origeniana (Bari 1975), 11-32; G. Dorival, «Remarques sur la forme du Peri Archon», en Origeniana (Bari 1971), 33-45; J. Rius-Camps, "Los diversos estratos redaccionales del Peri Archon de Orígenes», en RechAug 22 (1987), 5-65; G. Dorival, «Nouvelles remarques sur la forme du Traite des Principes d'Origene», en RechAug 22 (1987), 67-108; Ch. Kannengisser, "Origen, Systematician in De Principiis», en Origeniana quinta (Louvain 1992), 935-405; L. Lies, Origenes' Peri Archon. Eine undogmatische Dogmatik (Darmstadt 1992), 15-21; M. Simonetti, "Agl'inizii della filosofía cristiana: il De principiis di Origene», Vetera Christianorum 43 (2006) 157-173. 
do trabajo ${ }^{3}$. Liberados de divisiones artificiales, sobre la base, sobre todo, de la crítica interna del texto, proponemos la siguiente división del Пє@ì $\grave{\alpha} \varrho \chi \tilde{\omega} v$, cercana a la de Steidle:

\begin{tabular}{ll} 
Prin I, praef. & Prefacio \\
\hline Prin I, 1-4 & Dios (Padre, Hijo y Espíritu Santo) \\
Prin I, 5-8 & Los racionales \\
Prin II, 1-3 & El mundo \\
\hline Prin II, 4-7 & Dios (Padre, Hijo y Espíritu Santo) \\
Prin II, 8 - III, 4 & Los racionales \\
Prin III, 5-6 & El mundo \\
\hline Prin IV, 1-3 & La Escritura \\
Prin IV, 4 & Recapitulación
\end{tabular}

Pero, más allá de la estructura, no hay claridad acerca de la función, el carácter y la mutua relación de cada uno de los ciclos.

Ahora bien, el protagonismo del tema de la estructura del De principiis ha hecho que los estudiosos hayan abordado la cuestión del propósito del tratado de un modo más bien genérico. Por ejemplo, B. Steidle habla de una primera visión sintética y, luego, una visión más amplia y analítica; M. Harl, afirma que el primer ciclo es ordenado, general, global, concatenado y completo, que ofrece «una suerte de mirada de conjunto de las doctrinas", mientras el segundo ciclo es un conjunto de quaestiones particulares ${ }^{4}$; y J. Rius-Camps, por su parte, afirma que el primer ciclo es de carácter sapiencial, mientras el segundo es dogmático y de carácter preferentemente antimarcionita. P. Nautin, en cambio,

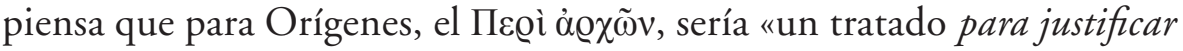
el conjunto de su doctrina» ${ }^{5}$. Esta falta de acuerdo invita a examinar más de cerca el carácter de cada una de las secciones para reconocer el propósito de la estructura del tratado ${ }^{6}$.

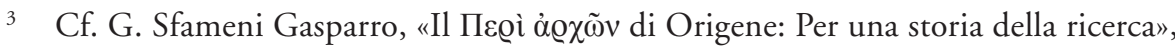
en Eadem, Origene e la tradizione origeniana in Occidente (Roma 1988) 237-295.

4 Cf. M. Harl, «Structure et cohérence du Peri Archôn», 16.

5 P. Nautin, Origène. Sa vie et son oeuvre (Paris 1977) 424.

6 Cf. H. Görgemanns - H. Karpp, Origenes vier Bücher von den Prinzipien (Darmstadt 1976) 16; J. Rius Camps, "Los diversos estratos redaccionales del Peri Archon de Orígenes», 11-14. 
El presente artículo busca reconocer el propósito de la estructura del De principiis y, por lo tanto, el carácter y la función de cada uno de los ciclos.

\section{La pedagogía divina y la Pedagogía de Orígenes}

Para comprender la obra origeniana es necesario tener en cuenta la gran preocupación pedagógica de Orígenes. La pedagogía divina, que adapta la Palabra para el beneficio del destinatario, es el modelo de la pedagogía del ministro de la Palabra. Orígenes destaca la capacidad de la Palabra divina de adecuarse a cada destinatario:

Diez personas, que tienen diez clases de enfermedades, van a un médico. Él no cura a todos del mismo modo [...]. Así también la Palabra de Dios se expresa de acuerdo con las características de los hombres y no esparce indistintamente los misterios de su sabiduría ${ }^{7}$.

Entonces, Dios no solo toma en consideración la diversidad de los pacientes, sino también el proceso gradual y el momento oportuno para actuar (xol@ós), adaptando el discurso a los oyentes. Pues, lo que en un momento daña, en otro sana; y lo que en un momento beneficia, en otro puede perjudicar. Por eso, Dios tiene en cuenta: «Qué se debe hacer con cada uno y cuándo». La voluntad de Orígenes por ser fiel a este principio de la acción divina queda de manifiesto en un texto que pude tener resonancias autobiográficas:

Quien haya podido contemplar el misterio de Cristo y del Espíritu Santo, y ver u oír lo que no es permitido pronunciar a los hombres, deberá tener la prudencia de la boca, sabiendo a quiénes, cuándo y cómo se debe hablar de los divinos misterios? ${ }^{9}$.

$7 \quad H E z$ III, 8 (las siglas de las obras origenianas son las de Origene: Dizionario : la cultura, il pensiero, le opere, a cura di A. Monaci Castagno, Roma 2000). Las metáforas del médico y de los alimentos destacan la necesidad de la adecuación al auditor y al momento, cf. OratXXVII, 9; HLvXVI, 2; CIo XXXII, 310-311; CMtX, 23-25; CCIV, 6.

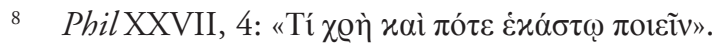

9 «Qui enim intueri potuerit mysterium de Christo et de Spiritu sancto et sive viderit sive audierit ea, quae non licet hominibus loqui, necessario habebit oris parsimoniam, sciens quibus vel quando vel quomodo de mysteriis divinis oporteat loqui», HNm XVII, 12 (GCS VII, 277). Cf. HNm IV, 3. 
De este modo, Orígenes insiste en que el intérprete de los misterios debe adecuar su discurso estando atento a tres elementos: el destinatario, el momento y la modalidad («quibus vel quando vel quomodo»), con el propósito de beneficiar a cada auditor con la palabra que requiere en el momento oportuno.

En síntesis, no solo hay un discurso adecuado para cada auditor, sino que también hay un discurso adecuado para cada momento del proceso del auditor. De acuerdo a esto, habría que prestar particular atención a los destinatarios reales del De principiis (quibus) y al itinerario que se ofrece para ellos (quando).

Si bien, algunos de estos textos pertenecen al período palestino, de todos modos nos muestran la sensibilidad pedagógica del Alejandrino. Ahora bien, volviendo a la estructura del tratado, la repetición de los mismos temas en los dos grandes ciclos del De principiis, teniendo en cuenta la sensibilidad pedagógica de Orígenes, parecería corresponder a dos ciclos sucesivos de enseñanza, con diferentes niveles de dificultad. Esta solución simple no resulta aceptable cuando uno constata que el primer ciclo no es más simple, sino más abstracto y especulativo que el segundo. Esta constatación, entre otras, ha llevado a J. Rius-Camps a elaborar una complicada teoría de diversos y sucesivos estratos redaccionales del tratado, en que Orígenes habría redactado primero el segundo ciclo y, posteriormente, el actual primer ciclo $^{10}$. A nuestro juicio, en cambio, la cuestión se puede explicar sin recurrir a la teoría de las redacciones sucesivas, sino por medio de una atenta consideración de los destinatarios del tratado.

\section{LOS DESTINATARIOS DEL DE PRINCIPIIS}

a. Orígenes, en una de sus cartas, asegura que se le acercaban tanto herejes como los que provenían de la educación griega, sobre todo filósofos ${ }^{11}$. Y Eusebio señala que "acudían a él con el fin de experimentar la pericia de este hombre en las doctrinas sagradas» ${ }^{12}$. Algunos de ellos, según Eusebio, "procedian de la ilustración y de la filosofía, y poco a poco se

10 Cf. J. Rius-Camps, «Los diversos estratos redaccionales del Peri Archon de Orígenes», 5-65.

11 Cf. Eusebio, HE, VI, 19, 12.

12 Eusebio, HE, VI, 18, 2 (BAC 350, p. 380). 
iban sometiendo a la enseñanza que él daba» ${ }^{13}$. Esta noticia acerca de los auditores del maestro de Alejandría ilumina un interesante texto en el que Orígenes describe el itinerario de Ambrosio, su mecenas, y justifica su propia producción literaria:

Así pues tú mismo [Ambrosio], por la ausencia de los [maestros] que se ocupan solícitamente de las cosas superiores y porque, en tu amor por Jesús, no soportabas una fe irracional y vulgar, habías adherido a las doctrinas [gnósticas], de las que después te apartaste ${ }^{14}$.

Según Orígenes, Ambrosio, al no encontrar una presentación racionalmente satisfactoria de la fe cristiana y al no poder tolerar "una fe

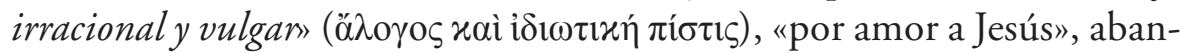
donó la Iglesia y adhirió a las doctrinas gnósticas ${ }^{15}$. Dos elementos fundamentales ofrece este texto: que en la comunidad eclesial existía un tipo de fe que era vista como irracional por los alejandrinos ilustrados, y que a causa de esta presentación de la fe, estos alejandrinos se sentían atraídos por el gnosticismo, que aparecía como una versión del cristianismo aceptable para alguien que no estaba dispuesto a abandonar la razón.

Otras fuentes confirman esta misma situación. Por una parte, según Celso, los cristianos exigían a sus seguidores «creer inmediatamente» (Cels VI, 7; VI, 10), y, como no eran capaces de argumentar, decían: "No investigues, sino cree» (Cels I, 9; III, 44; VI, 7-14), o simplemente: «Si quieres salvarte, cree o márchate» (Cels VI, 11); por lo mismo, solo llamaban a estúpidos e ignorantes: «El maestro cristiano anda en búsqueda de los necios» (Cels III, 74) y convocaban "a tontos, plebeyos, estúpidos, mujerzuelas y chiquillos» (Cels III, 49; I, 27; III, 18; 50; 55; VI, 12-13) ${ }^{16}$. $\mathrm{Y}$, por otra parte, el mismo Orígenes se lamenta de que la mayoría de los cristianos, que él llama los «simpliciores», no tienen interés por profundizar su fe y, por su negligencia, llegan a aceptar «fábulas estúpidas» y

13 Eusebio, HE, VI, 3, 13 (BAC 350, pp. 357-358).

14 In Io. Com., V, fr. VIII.

15 Cf. Eusebio, HE, VI, 18, 1.

16 Cf. S. Benko, «Pagan Criticism of Christianity During the First Two Centuries A. D.», en ANRW, II 23/2 (Berlin-New York 1980), 1055-1118; S. Fernández, «El Discurso verídico de Celso contra los cristianos. Críticas de un pagano del siglo II a la credibilidad del cristianismo», en Teología y Vida XLV (2004) 238-257. 
a pensar acerca de Dios «cosas que no se podrían pensar ni siquiera del más injusto de los hombres» ${ }^{17}$.

Esta fe irreflexiva era un obstáculo para los más inquietos intelectualmente $y$, en cambio, la vía gnóstica se presentaba como el único cristianismo racionalmente aceptable. Hay que recordar que, a inicios del siglo II, todavía no era fácil establecer con claridad los límites entre la comunidad eclesial y los grupos gnósticos ${ }^{18}$. En este contexto, Orígenes explica por qué él está dedicado a escribir libros:

Si nosotros calláramos, sin presentar contra los [heterodoxos] las doctrinas verdaderas y salvíficas, ellos se apropiarán de las almas más golosas ( $\lambda i \chi v o t)$, que por falta de alimento salvífico se lanzan ávidamente sobre los alimentos prohibidos, verdaderamente impuros y abominables ${ }^{19}$.

Este texto refleja la preocupación que impulsa a Orígenes a elaborar una exposición intelectualmente responsable del cristianismo, para que estos creyentes ilustrados de Alejandría, ávidos del alimento salvífico, no adhieran a las doctrinas gnósticas. Este dato ha sido confirmado por un texto, de contenido autobiográfico, perteneciente a las homilías sobre los salmos, recientemente restituidas a Orígenes:

En nuestra temprana edad florecían las herejías y parecían muchos los que se reunían en torno a ellas. Todos los que eran ávidos golosos ( $\lambda i$ ívoı) por las enseñanzas de Cristo, al no encontrar maestros adecuados en la Iglesia, a causa del hambre [de doctrina] imitaban a los que, en una hambruna, comen carne humana ${ }^{20}$.

Nuevamente aparecen estos alejandrinos «ávidos por las enseñanzas de Cristo», que atraídos por el gnosticismo, y que corresponden perfectamente con los griegos ilustrados descritos por la carta de Orígenes, por el fr. V del Comentario a Juan y por la Historia Eccesiastica de Eusebio.

17 Prin IV, 2, 2; CCt prol., II, 14; MtCom XVII, 35. Cf. G. af Hällström, Fides simpliciorum according to Origen of Alexandria (Helsinki 1984).

18 Cf. Eusebio, HE, VI, 2, 13-14; A. Jakab, «Alexandrie et sa communauté chrétienne à l'époque d'Origéne», en L. Perrone, Origeniana octava, vol. I (Leuven 2003) 93-104.

19 In Io. Com., V, fr. VIII.

20 SalHom 77, f. 233r. Cf. L. Perrone, «Riscoprire Origene oggi: prime impressioni sulla raccolta di omelie sui Salmi nel Codex Monacensis Graecus 314», en Adamantius 18 (2012) 41-58 
Y además, todos estos textos están referidos al ambiente y al período específico de la redacción del De principiis.

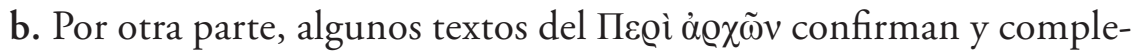
mentan estas observaciones. En el De principiis, Orígenes afirma que él escribe en función de los que «aún creyendo, acostumbran a escudriñar la razón en nuestra fe» (Prin IV, 4, 5) y para que su propio silencio «no alimente la insolencia de los herejes» (Prin II, 9, 6). Y busca «fortalecer la fe con la razón» (Prin IV, 1, 1). De hecho, cuando enfrenta el problema de la resurrección corporal, explicitando sus motivaciones, declara que se debe discutir acerca de la resurrección «sobre todo por el hecho de que algunos tropiezan con la fe eclesial, como si creyéramos de manera estúpida y necia acerca de la resurrección, especialmente los herejes» (Prin II, 10,1), y un poco después, rechaza la teología de aquellos cristianos que «por la estrechez de su entendimiento y la pobreza de su explicación, introducen una comprensión muy vulgar y baja de la resurrección del cuerpo» (Prin II, 10, 3) ${ }^{21}$. La combinación de estos datos permite

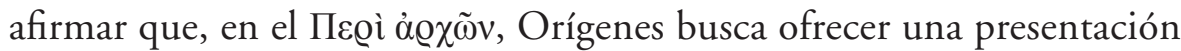
razonada de la fe eclesial, porque la fe de algunos creyentes aparece estúpida para un griego que no está dispuesto a abandonar la razón, y esto es motivo de tropiezo para estos cristianos ilustrados de Alejandría que no toleran una fe irracional.

Un interesante texto, esta vez del período palestino, refleja esta preocupación pedagógica y misionera. Se trata de la célebre homilía XX sobre Jeremías, que comenta el difícil texto: «Me engañaste, Señor» (Jr 20,7). Después de explicar la pedagogía divina, que se ofrece como paradigma, Orígenes explicita su propio método:

También nosotros, a veces, hacemos lo mismo [que Dios], cuando nos parece conveniente. En ocasiones, queriendo traer a los paganos a la fe, les dirigimos la palabra, y si vemos que están prejuiciados contra el cristianismo, que sienten horror por el Nombre y que odian escuchar: «Esta es una doctrina de los cristianos», simulamos pronunciar una doctrina útil, no propia de los cristianos; pero cuando nosotros, en la medida de nuestros medios, hemos establecido esta doctrina y nos parece bien ganar al oyente que casualmente no habría

21 Asimismo, en Contra Celso V, 14-18 Orígenes insiste en la necesidad de buscar una comprensión profunda de la fe en la resurrección. 
escuchado lo que se le había dicho, entonces declaramos que esta doctrina que alaba es la doctrina de los cristianos ${ }^{22}$.

El predicador, movido por una ardua dificultad exegética, lleva al extremo el método de adaptar el discurso en función del auditor. Si bien, esta homilía es un caso extremo, de todos modos, manifiesta, por una parte, hasta qué punto Orígenes es consciente de la dificultad que experimentan los paganos al escuchar algunas enseñanzas cristiana y, por otra, hasta qué punto reconoce que es necesario diseñar un camino para que los paganos puedan escuchar con fruto la enseñanza cristiana. Además, el mismo títu-

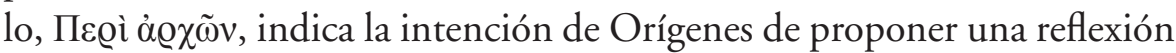
del pensamiento cristiano para el ambiente filosófico ${ }^{23}$.

De acuerdo a los textos estudiados, podemos suponer que Orígenes escribe el De principiis en función de personas ilustradas en la filosofía griega, que están interesadas de la enseñanza de Cristo, pero que, al no encontrar una presentación razonable de la enseñanza cristiana al interior de la comunidad eclesial, se sienten atraídas por el gnosticismo. De hecho, para estos cristianos, la enseñanza eclesial que conocen les parece un obstáculo para adherir a la Iglesia, porque, en algunos puntos, les parece irracional ${ }^{24}$.

\section{El itinerario que ofrece el De principis a sus destinatarios}

A la luz del estudio de los destinatarios y del propósito del De principiis, se podría comprender este tratado como un itinerario de enseñanza cristiana diseñado en función de estos cristianos ilustrados de Alejandría. Esta obra, entonces, buscaría ofrecer a estos creyentes un camino gradual de conocimiento de un cristianismo racionalmente coherente (diferente al cristianismo de los simpliciores), para darles una real alternativa frente a la atracción intelectual del sistema gnóstico. El programa de Orígenes consiste en lograr «una conciliación entre la ratio y la pietas» ${ }^{25}$.

22 In Jr. hom., XX, 5 (BPa 72, 343).

23 Cf. M. Simonetti, "Agl'inizii della filosofía cristiana: il De principiis di Origene», 157-158; G. Dorival, "Remarques sur la forme du Peri Archon», 33-45; Idem, «Nouvelles remarques sur la forme du Traite des Principes d'Origene», 67-108.

24 Cf. CC III, 73.

25 L. Perrone, "Vita da cristiano, pensiero greco?” L'eredità dell'Ellenismo nel cristianesimo di Origene», en L'Ellenismo come categoria storica e come categoria ideale (Milano 2013) 127. 
Dado el carácter de los destinatarios y la sensibilidad pedagógica de Orígenes, el itinerario no podía comenzar por las doctrinas cristianas más simples, para luego profundizar en las cuestiones filosóficas más complejas. Por el contrario, el itinerario debía abordar los obstáculos reales que dificultaban a los auditores a adherir a la comunidad eclesial. Pero, ¿cuáles eran esos obstáculos?

a. La difusión de la fides simpliciorum, de carácter irracional y vulgar, que fácilmente era identificada por los griegos ilustrados con el cristianismo eclesial.

b. Los reales puntos de conflicto entre el evangelio y el pensamiento griego.

Para comprender la estructura del De principiis, presentamos un par de ejemplos, referidos a cada uno de los obstáculos, que manifiestan la relación entre ambos ciclos y, por lo tanto, su función y propósito, para luego hacer un breve recorrido por cada uno de los capítulos del tratado.

a. Entonces, uno de los mayores obstáculos era la extendida impresión de que la fe eclesial era irracional, incompatible con la filosofía e incapaz de argumentar racionalmente, lo que resultaba intolerable para estos creyentes ilustrados, ávidos de conocimiento. Para proponer algún ejemplo concreto, recurrimos a una homilía sobre el Génesis que ofrece interesantes elementos, porque describe la estrechez de la fe de algunos critianos y muestra sus lamentables consecuencias:

Los judíos, pero también algunos de los nuestros, pensaron que Dios debía ser concebido a la manera de un hombre, es decir, dotado de aspecto y de miembros humanos, mientras que los filósofos desprecian estas cosas como míticas y como configuradas a semejanza de las ficciones poéticas ${ }^{26}$.

Y luego continúa diciendo que estos filósofos, que están fuera de la Iglesia, «nos ensordecen insolentemente diciendo que al Dios excelso, invisible e incorpóreo no le conviene tener comportamientos humanos». Ahora bien, mientras estos filósofos estén convencidos de que el cristianismo afirma que Dios es corporal, con aspecto de hombre, el acceso a la fe les está cerrado, por ello Orígenes siente la necesidad de aclarar que es posible

${ }_{26}$ In Gn. hom., III, 1. 
ser cristiano sin creer en un Dios corporal. Celso, en su Discurso verídico, confirma esta aversión filosófica a los antropomorfismos bíblicos ${ }^{27}$. Es fácil suponer que, en ese contexto, los creyentes más instruidos pensaban que el único cristianismo intelectualmente aceptable era el gnosticismo. Ahora bien, en concordancia con lo anterior, la mayor parte del tratado sobre Dios, contenido en el primer ciclo (Prin I, 1), está dedicado a reafirmar la total incorporalidad de Dios, de hecho, comienza así:

Sé que algunos se esforzarán, incluso sobre la base de nuestras escrituras, por afirmar que Dios es corpóreo (Prin I, 1, 1).

Esta afirmación no se dirige contra los filósofos estoicos, sino contra quienes argumentan con las escrituras, es decir, contra los cristianos que sostienen que Dios es corporal. Entre estos cristianos, no solo se cuentan los simpliciores, sino también algunos grandes autores cristianos de ambiente asiático ${ }^{28}$. De este modo, lo primero que Orígenes hace en el De principiis es rechazar la idea de que Dios es corporal, y así remover uno de los grandes obstáculos que impedían el acceso a la fe de los griegos ilustrados de Alejandría, marcados por la filosofía platónica. En términos negativos, busca mostrar que el cristianismo no es una doctrina vulgar, es decir, una estupidez; y en términos positivos, busca reafirmar que el cristianismo es compatible con la razón. De este modo, para seguir las enseñanzas de Cristo, no había que elegir entre la opción «irracional» de la comunidad eclesial y la opción «filosófica» de los gnósticos.

Por su parte, el tratado sobre Dios, contenido en el segundo ciclo (Prin II, 4-5), está consagrado a la identidad entre el Dios del AT y del NT,

27 Ver CC VII, 34; IV, 14; VI, 71; IV, 73; IV, 72; VIII, 13.

28 Según Orígenes, estos cristianos se apoyan en los antropomorfismos bíblicos, cf. $H G n$ III, 1; HNm XXIII, 2; HGn VIII, 10; CCt III, 13, 46; CIo XIII, 125; Orat XXIII, 3. Estos mismos cristianos son blanco de las críticas de Celso (CCVII, 34; IV, 14; VI, 71; IV, 73; IV, 72; VIII, 13). Además, otros sostienen que Dios es corporal, por influencia estoica (interpretación materialista de Jn 4, 24) o porque consideran que la imagen de Dios reside en el cuerpo, cf. $H G n$ I, 13; Heracl 12; Gn 1, 26. En $C R m$ I, 19 Orígenes habla contra los antropomorfitas que pertenecen a la Iglesia, y en GnCom menciona entre ellos a Melitón de Sardes (CChG 15, 72; PG XII, 93a-b). Tertuliano, a propósito de Jn 4, 24, afirma que el Espíritu es un cierto género de cuerpo: «¿Quién negará que Dios es cuerpo, y si bien Dios es espíritu, el espíritu es un género particular de cuerpo (corpus sui generis)", Adv. Prax., 7, 8; cf. Carn., 11, 4; Anim., 5, 2 (se apoya en los estoicos). Y Así, los partidarios de un Dios corpóreo no se cuentan solo entre los simplones, sino también entre los cristianos ilustrados de tradición estoica (cf. Clemente, Strom., V, 89, 2), en especial, de tradición asiática. 
entre el Bueno y el Justo, con un carácter prevalentemente antignóstico y antimarcionita. De este modo, en el tratado sobre Dios, mientras en el primer ciclo toma distancia de la fides simpliciorum, y no polemiza contra los gnósticos, en el segundo ciclo toma distancia de los gnósticos y marcionitas y se expresa de modo mucho más cercano al kerigma eclesial.

b. Con un otro ejemplo, quisiéramos ilustrar cómo Orígenes enfrenta el segundo de los obstáculos que enfrentan los griegos ilustrados para acceder a la fe cristiana, es decir, los reales puntos de conflicto entre el evangelio y el pensamiento griego. En una homilía sobre el Génesis, Orígenes explicita algunos puntos de conflicto entre la filosofía y la doctrina cristiana:

Pero [la filosofía] disiente de nosotros cuando dice que la materia es coeterna con Dios o cuando sostiene que Dios no se ocupa de los seres mortales, sino que su providencia se reduce a los espacios supralunares. Están en desacuerdo con nosotros cuando hacen depender la vida de la posición de las estrellas al momento de nacer y cuando dicen que este mundo es eterno y no tendrá $\mathrm{fin}^{29}$.

En otra homilía, esta vez sobre el Éxodo, afirma:

Cuando dices [a los infieles] que el Señor de la majestad fue crucificado y que el Hijo del hombre es el que ha bajado del cielo, ¡cuán tortuosas y difíciles parecen estas cosas $!^{30}$.

Ciertamente, el elenco no es completo, pero permite hacerse una idea de los puntos de conflicto entre el pensamiento griego y el cristianismo auténtico (y no solo entre el pensamiento griego y un cristianismo deformado, como el de los simpliciores).

Para ilustrar esta situación, basta comparar el tratado sobre el Hijo en el primer y segundo ciclo. Tal como se ha visto, uno de los puntos conflictivos es la encarnación, y en el primer ciclo, la encarnación casi no es mencionada, sino que es desarrollada la identidad divina del Hijo y su relación con el Padre. En cambio, en el segundo ciclo, sí se aborda el tema de la humanidad del Hijo, con un lenguaje cercano al kerigma eclesial y con algunas insistencias antignósticas.

$29 \quad H G n$ XIV, 3. Cf. HLv VII, 6; HIer XVI, 9; HIos VII, 7.

30 HEx $\mathrm{V}, 3$. 
Otro ejemplo interesante se refiere al modo de presentar la escatología. En este punto, se combinan ambos obstáculos: por una parte, la fides simpliciorum sobre la resurrección insiste de modo burdo sobre el carácter material de la resurrección (hasta despertar el rechazo entre los griegos); pero, por otra parte, aun resueltos los malos entendidos, de todos modos la fe cristiana en la resurrección corporal entra en conflicto con la mentalidad helenista. De este modo, cuando Orígenes aborda el destino final del hombre, en el primer ciclo (Prin I, 6), no desarrolla el tema de la resurrección corporal (que es chocante para la mentalidad platónica), sino que trata de la unidad del final y el inicio de manera más «filosófica»; en cambio, en el desarrollo de la escatología en el segundo ciclo (Prin II, 10-11), después de aclarar que la fe eclesial no sostiene una idea material de las promesas, solo entonces puede proponer la resurrección de la carne y atacar la teología gnóstica que la negaba.

Entonces, podemos reconocer un doble propósito a la disposición pedagógica de los ciclos del De principiis: en términos negativos, el primer ciclo busca mostrar que el cristianismo eclesial no era una estupidez y, en términos positivos, mostrar que la fe eclesial es compatible con la razón griega y capaz de insertarse plenamente en los grandes debates de la filosofía de la época. Luego, en el segundo ciclo, cuando los auditores ya distinguen con claridad la fe cristiana de la fides simpliciorum y están suficientemente convencidos de la compatibilidad de la fe eclesial con la razón, y que, por lo tanto, ya se sintieran menos atraídos por el gnosticismo, solo entonces realiza la crítica al gnosticismo y proponer un discurso más cercano al lenguaje bíblico y al kerigma eclesial. En palabras muy simples: en el primer ciclo, toma distancia de la vulgar fe de los simplones, con un discurso más filosófico; mientras en el segundo ciclo, toma distancia de los gnósticos, con un discurso más eclesial.

\section{Contenido y propósito de las Secciones del De PRINCIPIIS}

a. Contenido y carácter del prefacio (Prin I, praef.)

El prefacio busca clarificar cuáles son los puntos centrales de la predicación eclesiástica y mostrar que la fe eclesial no reemplaza la investigación racional, sino que la impulsa. Además, afirma el carácter unitario de la doctrina cristiana, es decir, que tiene coherencia racional interna y, por ello, es capaz de conformar un «cuerpo único». 
b. Contenido y carácter del primer ciclo (Prin I, 1 - II, 3)

La primera sección del De principiis tendría como objetivo marcar una fuerte distancia entre la genuina enseñanza cristiana -tal como la concibe Orígenes- y la fe de los simpliciores y, a la vez, mostrar que el cristianismo eclesial es capaz de participar en los grandes debates de la filosofía contemporánea. Pues, tal como ha señalado M. Simonetti, con el De principiis, Orígenes busca insertar la reflexión cristiana en la tradición de la filosofía griega ${ }^{31}$.

Prin I, 1 (sobre Dios). Refuta a los que afirman que Dios es corpóreo y, así, toma distancia de los simplones e inscribe su reflexión en la tradición platónica, tomando distancia del estoicismo y de los cristianos de tradición asiática (diferentes de los simpliciores). Argumenta con la razón, y no utiliza la escritura como autoridad, sino que clarifica la correcta interpretación de algunos versículos.

Prin I, 2 (sobre Cristo). Habla de Cristo en cuanto Dios, el cual, en cuanto Sabiduría, no es corporal, e insiste en el carácter espiritual y eterno de la generación del Hijo (busca explicar de modo razonable la unidad y distinción entre el Padre y el Hijo). Tampoco se vale de la escritura como autoridad, y evita desarrollar lo más chocante para un griego ilustrado: la encarnación.

Prin I, 3-4 (sobre el Espíritu Santo y la acción divina). Advierte de la novedad del Espíritu Santo en relación con la tradición filosófica (a diferencia de Dios Padre y de su Logos). Muestra la necesidad del Espíritu Santo para que se complete la obra de Dios. Enfrenta el problema de la protología, tema debatido por filósofos y gnósticos, pero excluido por los simpliciores y por cristianos de tradición asiática ${ }^{32}$.

Prin I, 5-8 (sobre las creaturas racionales). Insiste en que la actual diversidad de los racionales no es culpa del Creador, sino producto del libre albedrío; muestra el carácter medicinal de los castigos y rechaza el fatalismo astral (en estos temas, la polémica antignóstica está presente de modo implícito). Reflexiona sobre la unidad del final y el inicio, y

31 Cf. M. Simonetti, "Agl'inizii della filosofía cristiana: il De principiis di Origene», 157-173.

32 Cf. Ireneo evita este tipo de especulación: «Si alguno pregunta: ¿Qué hacía Dios antes de crear el mundo? Le diremos que ese es un problema de Dios» (Adv. haer., II, 28, 3); Tertuliano, Praescr., VII, 5. 
argumenta de modo muy abierto sobre la suerte final de las realidades visibles y sobre la vida de los astros, temas discutidos entre los filósofos.

Prin II, 1-3 (sobre el mundo). Con un estilo filosófico, reflexiona sobre el mundo, su definición, su unidad, sobre la hipótesis de los mundos sucesivos, y sobre el origen, la condición y el destino de la materia. En algunas cuestiones toma postura, otras las deja abiertas. Normalmente, argumenta con la razón y confirma con la escritura.

c. Contenido y carácter del segundo ciclo (Prin II, 4-IV, 3)

Una vez que el auditorio ya se ha convencido suficientemente de que la enseñanza eclesial no implica las absurdas ideas que profesan los simpliciores, Orígenes estaba en condiciones de ofrecer el segundo ciclo que ataca más directamente a gnósticos y marcionitas, y que abordara de modo más directo, con la autoridad de la escritura, las doctrinas eclesiales más chocantes para la razón griega:

Prin II, 4-5 (sobre Dios). Orígenes ataca la doctrina marcionita con argumentos que no están dirigidos a los marcionitas (pues utiliza Mt y Hech), destaca la unidad del Dios del AT y del NT, rechaza la interpretación literal del AT y responde a las acusaciones gnóstico-marcionitas contra la enseñanza eclesial. Argumenta con la autoridad de la escritura y con la razón.

Prin II, 6 (sobre Cristo). Parte con una advertencia sobre el carácter admirable y asombroso de la encarnación e insiste en la dificultad de afirmar la divinidad y la humanidad en un solo sujeto. Argumenta con la escritura y destaca la diferencia entre Jesús y un profeta.

Prin II, 7 (sobre el Espíritu Santo). Por primera vez menciona a Valentín y a Marción, e implícitamente ataca a los montanistas. Además, con función antignóstica, insiste en que todos pueden poseer el Espíritu Santo.

Prin II, 8-9 (sobre las almas). De modo muy «investigativo» ( $\gamma \cup \mu v \alpha \sigma \tau 1 x \tilde{\omega} \varsigma)$, argumentando con la razón y la Biblia, se pregunta primero por las almas y por la causa de la diversidad. Y, en explícita polémica contra los gnósticos, resuelve el problema sobre la base de la preexistencia de las almas.

Prin II, 10-11 (sobre la resurrección, el juicio y las promesas). Con mayor vinculación a la predicación eclesiástica, aborda el tema de la re- 
surrección y del final. Polemiza contra los herejes que niegan la resurrección corporal (gnósticos) y, a la vez, ataca ideas demasiado materiales de la resurrección (los simpliciores y milenarismo asiático). Insiste en que el pecador es autor de sus castigos y así defiende la bondad de Dios.

Prin III, 1-4 (sobre el libre albedrío y el influjo del diablo). Busca explicar el contenido de la predicación eclesiástica por medio de la razón y de la escritura. Esta sección es polémica: contra los que atacan al Creador, niegan el libre albedrío e introducen las naturalezas, es decir, es antignóstica y antimarcionita. Niega que el influjo del diablo sea irresistible.

Prin III, 5-6 (sobre el inicio y sobre el final). Parte del dato revelado y argumenta con la razón. A partir de la fe de la Iglesia, rechaza dos doctrinas muy difundidas en la cultura helenística: la eternidad del mundo y el fatalismo, y tiende a defender el carácter corporal de la resurrección, contra la sensibilidad griega.

Prin IV, 1-3 (sobre la escritura). Primero busca probar racionalmente la inspiración de la escritura, mostrando que las profecías se cumplen en la historia de Jesús y de sus discípulos. Luego aborda el problema de su interpretación: rechaza la exégesis literal (de judíos, gnósticos y simpliciories) y afirma que la coherencia de la escritura se da a nivel espiritual. Finalmente, después de mostrar la imposibilidad de una interpretación literalista, ofrece una explicación espiritual del conjunto de la historia del AT.

d. Contenido y carácter de la «recapitulación o reconsideración» (Prin IV, 4)

En la llamada «Recapitulación», Orígenes retoma algunos puntos particulares que no estaban suficientemente tratados en los ciclos anteriores. En el orden del texto se aprecia una irregularidad: trata primero de Dios, luego del mundo y, finalmente, de las creaturas racionales. Esta sección muestra el carácter inacabado de la obra.

\section{Carácter y Relación de los dos grandes ciclos del De PrinCipiss}

De este modo, el tratado estaría constituido por el prefacio, dos amplias secciones y una recapitulación. Cada una de estas partes trata de Dios, los racionales y el mundo. Si bien, sería artificial establecer una distinción neta entre ambas partes, se pueden apreciar ciertas características 
prevalentes que muestran la diferencia entre ambas partes, consideradas como conjunto (no en cada detalle). El primer ciclo es más bien propositivo: está desarrollado «más en función de la comprensión lógica que de la definición dogmática» (Prin I, 7, 1) y busca «debatir más que definir» (Prin I, 6, 1); está en diálogo con los problemas de la filosofía de la época imperial, y toma clara distancia de la fe de los simpliciores y de la teología asiática (Dios corpóreo, interpretación material de las promesas, etc.); explica la escritura sin usarla como autoridad, evita los temas más chocantes para la mentalidad helenista y la polémica antignóstica es solo implícita. El segundo ciclo es antiherético de modo más explícito, de hecho, cuando inicia el segundo ciclo afirma: «ahora corresponde confutar» a los que imaginan un Dios del AT diferente al del NT (Prin II, 4, 1); el segundo ciclo es más cercano al lenguaje de la predicación eclesiástica, usa la Biblia como autoridad y aborda los temas más chocantes para la mentalidad helenística (encarnación, resurrección corporal, inicio temporal del mundo, etc.).

La estructura que hemos propuesto no explica satisfactoriamente muchas anomalías que presenta el tratado. La ubicación, sucesión y amplitud de diversos temas siguen sin una explicación clara ${ }^{33}$. Y entonces, ¿cómo explicar las anomalías de la disposición de las diversas secciones del De principiis?

Más que pretender explicar cada anomalía, tal vez la solución consista en reconocer una relativa falta de orden del texto, como ha recordado M. Simonetti, debido al carácter inacabado del tratado, dato que cuenta con cierto fundamento en los escritos origenianos. Orígenes, en una carta, se queja de no contar con el tiempo para revisar y corregir sus escritos $^{34}$, y en otra carta, dirigida al papa Fabián y transmitida por Jerónimo, en que se defiende de la acusación de haber afirmado la salvación de demonio, sostiene que Ambrosio hizo público lo que él había escrito para uso privado ("Quod secreto edita in publicum protulerit» ${ }^{35}$ ). Si bien, el fragmento de la carta no lo dice explícitamente, el escrito aludido por

33 La anomalías de la estructura del De principiis, han sido señaladas por J. RiusCamps, "Los diversos estratos redaccionales del Peri Archon de Orígenes», 5-65.

34 Cf. P. Nautin, Lettres et écrivains chrétiens des II et III siècles (Paris 1961), 250-251

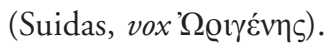

35 Apud Jerónimo, Ep., 84, 10; cf. Eusebio, HE, VI, 36, 4. 
la carta posiblemente es el De principiis $^{36}$, y el imprudente entusiasmo de Ambrosio por difundir el escrito se explicaría por el hecho de que este tratado contendría la enseñanza que le permitió a él mismo regresar a la comunidad eclesial después de haber adherido a las enseñanzas de Valentín ${ }^{37}$. Esta situación explicaría la relativa falta de orden del tratado.

\section{CONCLUSIÓN}

La mirada a cada una de las secciones permite confirmar el carácter más filosófico del primer ciclo y la mayor adherencia a la tradición eclesiástica del segundo ${ }^{38}$, y permite apreciar el propósito pedagógico del De principiis: luego de clarificar en el prefacio los puntos esenciales del kerigma, el primer acercamiento a la fe eclesial de estos creyentes ilustrados, tentados por el gnosticismo, no podía estar marcado por un discurso explícitamente antignóstico: se debía demostrar primero la armonía entre la auténtica doctrina eclesial y la razón griega y, por otra parte, mostrar que la doctrina eclesial no se identificaba con la fe irracional denunciada por Celso y profesada por los simpliciores. Este primer ciclo, en la mente de Orígenes, debía contar con el segundo ciclo: solo así se entiende que al tratar de Dios Padre en el primer ciclo haya dejado fuera tantos elementos importantes, que el capítulo sobre el Hijo casi no mencione la encarnación, o que en la discusión acerca del final no se refiera a la resurrección corporal (Prin I, 1; I, 2; I, 6). En el primer ciclo, el maestro alejandrino busca evitar los temas más chocantes para un griego instruido y que podían aparecer más vinculados con la doctrina de los simpliciores. Así se explica que el primer ciclo no esté constituido por una enseñanza elemental, sino sofisticada, sin recurrir a la hipótesis de que la primera parte fue escrita en un segundo momento ${ }^{39}$. Una vez logrados los ob-

36 Cf. F. Prat, Origène, le théologien et l'exégète (Paris 1907), 2; M. Simonetti, "Agl'inizii della filosofía cristiana: il De principiis di Origene», 163.

37 Eusebio, HE, VI, 18, 1: «También Ambrosio, que tenía las opiniones de la herejía de Valentín, convencido por la verdad presentada por Orígenes y como si una luz le hubiera iluminado la mente, dio su asentimiento a la doctrina de la ortodoxia eclesiástica».

38 Cf. M. Simonetti, "Agl'inizii della filosofía cristiana: il De principiis di Origene», 162-165.

39 Joseph Rius-Camps propuso una detallada explicación de la estructura actual del tratado ensayando una reconstrucción de diversas y sucesivas etapas de la redacción, que no corresponden al orden actual de la obra: un ciclo dogmático (actual segundo ciclo: Prin II, 4-IV, 3); un ciclo sapiencial (actual primer ciclo: Prin I, 
jetivos del primer ciclo, solo entonces el De principiis aborda los temas más chocantes para el espíritu griego con una perspectiva más bíblica y antiherética.

¿Refleja el De principiis la actividad escolástica de Orígenes? Si bien, la estructura pedagógica del tratado y el estilo investigativo del texto sugieren su origen escolástico, las fuentes disponibles afirman que la enseñanza de Orígenes consistía en un ciclo filosófico y luego otro dedicado a la interpretación de la escritura, lo que no dejaría lugar a una enseñanza sistemática de la teología ${ }^{40}$. Pero, hay que reconocer que las fuentes que describen la enseñanza de Orígenes en Alejandría son escasas y fragmentarias, y por ello tampoco parece que se pueda negar al menos una estrecha relación entre el De principiis y la actividad escolástica del maestro alejandrino.

En síntesis, el De principiis estaría básicamente estructurado por dos ciclos sucesivos pensados como un itinerario pedagógico para introducir en la enseñanza eclesial a un tipo de cristiano, de alta formación griega, que desprecia la fe de los simpliciores y que se siente atraído por la opción intelectual de los gnósticos. Estos sucesivos desarrollos de los mismos temas bajo diversas perspectivas, no serían fruto de sucesivas redacciones, sino más bien de un plan pedagógico proyectado por Orígenes.

1-II, 3); un tercer estrato redaccional (inserciones específicas en Prin I, 3 - III, 6) y un cuarto estrato redaccional (Prin IV, 4). Pero es difícil aceptar esta sofisticada hipótesis al ver la persistente falta de orden del tratado, que si hubiera tenido tantas revisiones y modificaciones, habría sido eliminada.

40 Cf. M. Simonetti, I Princîpi di Origene (Torino 1968) 32. 
